\title{
PERCEPTIONS ABOUT ACCREDITATION AND QUALITY MANAGEMENT IN HIGHER EDUCATION. \\ DEVELOPMENT OF A SPANISH-LANGUAGE QUESTIONNAIREWITHASAMPLEOF ACADEMICS FROM A PRIVATE UNIVERSITY
}

\author{
Luis González-Bravo', Dorin Stanciu ${ }^{2}$, Nicolae Nistor ${ }^{3}$, \\ Bernardo Castro $^{4}$, Gonzalo Puentes ${ }^{5}$, Maruzzella Valdivia ${ }^{678}$
}

\begin{abstract}
Quality improvement policies occupy a central place in higher education and represent important requirements for educational institutions in a globalized economy, and qualityrelated processes legitimacy is enhanced by the participation of academic community. Therefore, the purpose of this study is to develop and validate a Spanish-language scale intended to assess perceptions about the accreditation process and the quality management in Higher Education Institutions. Based on prior findings, and using a one-time, cross-sectional design, 339 academics across four Chilean major academic cities were surveyed. Using structural equation modeling, two solutions with adequate fit indices were found: a four-factor solution comprised of Institutional relevance of accreditation, Objectivity of accreditation evaluation, Internal Quality Unit relevance for accreditation, Value of accreditation to educational system, as main constructs, and a six-factors solution, which included two additional constructs, i.e., Continuous Quality Management value and Students' participation value.

The questionnaire developed in our research allows higher education institutions to objectively assess and quantify the benefits of quality management and accreditation. Its results are particularly pertinent for countries with Spanish as an official language, taking into account the importance of internationalization of higher education.
\end{abstract}

Key concepts: Accreditation; Higher Education; Quality Management; Scale Development; Faculty Perceptions; Latin America; Structural Equation Modeling

\footnotetext{
Universidad de Concepción, Concepción, Chile. Contacto: lgonzalez@udec.cl

Technical University Cluj-Napoca, Cluj-Napoca, Rumania.

Contacto: ionut.stanciu@dppd.utcluj.ro

3 Ludwig-Maximilians-Universität München, Múnich, Alemania.

Contacto: nic.nistor@uni-muenchen.de

4 Universidad de Concepción, Concepción, Chile. Contacto: becastro@udec.cl

5 Universidad San Sebastián, Santiago, Chile. Contacto: gonzalo.puentes@uss.cl

6 Universidad de Concepción, Concepción, Chile. Contacto: mavaldivia@udec.cl

7 Luis González Bravo and Dorin Stanciu have equally contributed to this article having thus both first author status.

8 Both Dr. Nistor and Dr. Stanciu are also academics at Walden University, Richard W. Riley College of Education and Leadership.
} 

OF ACADEMICS FROM A PRIVATE UNIVERSITY - L. González-Bravo, D. Stanciu, N. Nistor, B. Castro, G. Puentes, M. Valdivia

\title{
PERCEPCIONES ACERCA DE LA ACREDITACIÓN Y LA GESTIÓN DE LA CALIDAD EN LA EDUCACIÓN SUPERIOR. DESARROLLO DE UN CUESTIONARIO EN CASTELLANO CON UNA MUESTRA DE ACADÉMICOS DE UNA UNIVERSIDAD PRIVADA
}

\begin{abstract}
RESUMEN
Las políticas de mejoramiento de la calidad ocupan un lugar central en la educación superior y representan requisitos importantes para las instituciones educativas en una economía globalizada, en tanto que la legitimidad de los procesos relacionados con la calidad se ve reforzada por la participación de la comunidad académica. En consecuencia, el propósito de este estudio es desarrollar y validar una escala en castellano destinada a evaluar las percepciones sobre el proceso de acreditación y la gestión de la calidad en las Instituciones de Educación Superior. En base a hallazgos anteriores, y utilizando un diseño transversal en un solo momento en el tiempo, se encuestaron 339 académicos en cuatro ciudades académicas importantes de Chile. Utilizando el modelado de ecuaciones estructurales, se encontraron dos soluciones con indices de ajuste adecuados: una solución de cuatro factores que incluye Relevancia institucional de la Acreditación, Objetividad de la evaluación de acreditación, Relevancia de la Unidad de Calidad Interna para la acreditación, Valor de la acreditación para el sistema educativo, como principales constructos, y una solución de seis factores, que incluyó dos constructos adicionales: el Valor de la gestión continua de la Calidad y el Valor de la participación de los Estudiantes. El cuestionario desarrollado en nuestra investigación, permite a las instituciones de educación superior evaluar y cuantificar objetivamente los beneficios de la gestión de la calidad y la acreditación. Sus resultados son particularmente pertinentes para países con el castellano como lengua oficial considerando la importancia de la internacionalización de la educación superior.

Conceptos Clave: Acreditación; Educación Superior; Gestión de la Calidad; Desarrollo de Escalas; Percepciones de Académicos; América Latina; Modelos de Ecuaciones Estructurales
\end{abstract}




\section{Introduction}

The need to clarify the effects of quality systems on educational institutions, in terms of empirical evidence of perceptions and attitudes about accreditation is increasingly relevant (Cardoso, Rosa, $\&$ Santos, 2013; Cardoso, Rosa, \& Stensaker, 2015). The study of opinions and attitudes of academics regarding quality assurance/ management in university education has gradually gained recognition as a field of research in itself (Larrauri, Espinosa, Rosario Muñoz, \& Lechosa, 2012), and has experienced significant development during recent decades in countries like the United Kingdom, US (Larrauri et al., 2012), Portugal (Cardoso, 2009; Cardoso et al., 2013; Cardoso et al., 2015; Cardoso, Rosa, \& Videira, 2018) and Chile (IPSOS, 2010b; Lemaitre, Maturana, Zenteno, \& Alvarado, 2012; Zapata \& Torre, 2012).

A distinction must be made between quality assurance and quality management in higher education. Although difficult, since there is not such a clear separation in the literature (Manatos, Sarrico, $\&$ Rosa, 2017), it is possible to assert that quality assurance consists of the existence of mechanisms, procedures and processes to ensure that a desired quality standard is achieved. To guarantee this quality and its improvement, quality assurance must be a cyclical process and must consider at least a measurement of educational quality, a judgment based on standards and an improvement based on priorities and plans. (Dolmans, Wolfhagen, \& Scherpbier, 2003). There are external quality assurance systems -for example, government or private agencies- and internal ones, which the institution itself creates and manages (Cabrera Lanzo, 2018). Quality assurance implies a strong component of accountability, testing against standards, and ultimately, control (CNA-Chile, 2015: 4).

This notion is being replaced by the concept of quality management (QM), which emphasizes continuous development and improvement, rather than just responding to external certifications. It has a strong component of cultural change, where the different members of the organization are committed to continuous improvement processes (González-Bravo, Nistor, \& Castro Ramírez, 2019). 
324 PERCEPTIONS ABOUT ACCREDITATION AND QUALITY MANAGEMENT IN HIGHER EDUCATION. DEVELOPMENT OF A SPANISH-LANGUAGE QUESTIONNAIRE WITH A SAMPLE OF ACADEMICS FROM A PRIVATE UNIVERSITY - L. González-Bravo, D. Stanciu, N. Nistor, B. Castro, G. Puentes, M. Valdivia

Despite the importance of HEI professionals' participation in these quality assurance or quality management processes, relevant quantitative Spanish-language instruments, with adequate psychometric properties, are not reported in the literature. The perception that academics, managers and the university community have about quality and self-assessment are relevant for the sustainability of institutions and the need to achieve and promote adequate quality improvements. According to the World Bank, improving quality levels of higher education in Latin America, as well as having the appropriate instruments are of international interest when facing internationalization processes in a globalized economy (Ferreyra, Avitabile, \& Paz, 2017).

The purpose of this study is to develop and validate a Spanish-language scale intended to assess the perceptions about the accreditation process and the quality management in Higher Education Institutions. The theoretical framework of this paper addresses the following points: a) benefits of accreditation as a selfassessment process, b) value of accreditation to Latin-American educational systems, c) peer-review roles and state guidelines, d) value of the internal quality unit, e) student participation, and f) continuous quality management. Consequently, based on a thorough literature review, four existing questionnaires, utilized in previous studies with similar interests, were selected and translated into Spanish by bilingual experts. After exploratory and confirmatory factor analysis, a final questionnaire was proposed.

\section{Theoretical Framework}

The literature regarding perceptions of quality and accreditation in HEIs is currently led by three major approaches, according to the functional roles of the population of interest within the educational centers. The first approach includes studies that compare perceptions between different institutional levels. In this regard, the most relevant research was conducted by Putnam (2000), which included presidents, full-time faculty members, chief administrative officers, and governing board members, and by Vieira (2002), which included students and faculty. The second approach consists of studies focusing 
on assessing the students' perceptions (Cardoso, 2009; Volkwein, Lattuca, Harper, \& Domingo, 2007). Finally, the third perspective stems from studies that focused on evaluating the perceptions of managers and academics about these issues (Cardoso et al., 2013; Cardoso et al., 2015; Cardoso et al., 2018; Gregorutti \& Bon, 2012; Newton, 2002; Trullen \& Rodríguez, 2013).

The main findings about these processes on HEIs are presented below, organized into main topics that the literature review regarding perceptions about accreditation and quality management, has indicated as relevant (Busco, Dooner, \& d'Alencon, 2018; Cardoso et al., 2013; Cardoso et al., 2015; IPSOS, 2010b; Kleijnen, Dolmans, Willems, \& van Hout, 2011; Lemaitre, Maturana, Zenteno, \& Alvarado, 2011; Scharager, 2017; Zapata \& Torre, 2012).

\section{Benefits of Accreditation as a Self-Assessment Process}

Generally, faculty support quality and accreditation processes, as long as these do not interfere in their daily activities (Laughton, 2003), and appreciate that these processes can serve the quality of teaching and learning (Cardoso et al., 2013; Huusko \& Ursin, 2010; Kleijnen et al., 2011). In 2006, the New England Association of Schools and Colleges (NEASC) conducted research on educational institutions at different levels. For HEIs, a sample of college and university presidents selected from a blend of 16 public and 14 independent institutions was surveyed. The main findings included that $97 \%$ of respondents agreed that accreditation "fulfilled the function of 'promoting quality' at their institution" (which is accomplished through the continuous improvement of different processes); 100\% believed that accreditation "fulfilled the function of providing public assurance of the quality of education" at their institution; the $97 \%$ of respondents agreed that "participation in accreditation was useful to faculty and staff at their institution" (NEASC, 2006, p. 20).

The direct benefits of accreditation, indicated by academic personnel, included faculty recruitment, infrastructure improvement, curricular redesign and other aspects, as pointed out by De Vincenzi (2013) who conducted document analysis and semi-structured interviews in three universities in Argentina, spanning the period 
326 PERCEPTIONS ABOUT ACCREDITATION AND QUALITY MANAGEMENT IN HIGHER EDUCATION. DEVELOPMENT OF A SPANISH-LANGUAGE QUESTIONNAIRE WITH A SAMPLE OF ACADEMICS FROM A PRIVATE UNIVERSITY - L. González-Bravo, D. Stanciu, N. Nistor, B. Castro, G. Puentes, M. Valdivia

of 2000-2005. De Vincenzi (2013) found that organizational changes produced by accreditation were due to different political or contextual factors, such as perceptions about educational quality or state regulations. Regarding institutional evaluation, even though respondents valued the validity of the evaluation, they also reported that they only did it systematically when the State demanded it. In addition, although there had been changes in teaching, research and extension to the community, these have often been the results of external pressures and requirements rather than outcomes of a natural internal development process.

The findings reported above are consistent with those identified in Salas Durazo's (2013) qualitative study, and in Zapata and Torre's (2012) and Busco et al.'s (2018) mixed qualitativequantitative research. Based on the in-depth interviews of four career coordinators and one common curricular specialist, Salas Durazo (2013) found that the introduction of accreditation in Mexico City transformed teaching and administrative practice, especially in the field of planning and management tools, e.g., planning, development and evaluation of the courses. This positively influenced the related decision-making process and led to an improvement in teaching and in the administrative practice of HEIs (Salas Durazo, 2013).

Busco et al. (2018), in a case study at Universidad de Chile, reported significant effects of accreditation in three main areas: organizational learning, cultural shift, and university and stakeholders. At managerial levels, the authors identified positive effects in "data gathering and information access, planning of curricula and teaching, professors' career development, and relationships with the international environment" (Busco et al., 2018, p. 445). Despite the aforementioned, self-assessment produced internal tensions on a cultural level, associated with extra work and lack of recognition of functions. Along the same lines of empirical evidence, a new style of decision-making that incorporates the results of self-evaluation in the field of teaching is reported in a quantitative-qualitative study developed by Zapata and Torre (2012) who reported that a greater value to teaching is added. 
In Chile, the main effects of accreditation are observed in institutional management, e.g., diagnostic capacity, 90.3\%; and information management, 85.9\% (IPSOS, 2010a, 2010b). In IPSOS' seminal study for Chile, $93.8 \%$ of the respondents considered that accreditation contributed to improvement of quality of institutional management, while other areas benefited were observed such as undergraduate teaching (87.5\%), program offerings (76.6\%), teaching processes (76.1\%), graduate follow-up (74.1\%) and research (51.6\%). To a lesser extent, postgraduate programs (42.8\%) and community linkage were observed in certain specific areas: definition of public policies (82.7\%) and formalization of the link with the community (81.6\%) (IPSOS, 2010a, 2010b).

Newton (2002) revealed that professors do not passively accept the particular changes or demands of quality assurance policies or systems, and that policy implementation is perceived as complex and uneven. Faculty members are not inert recipients of management objectives; instead, academic staff, together with all actors involved, are 'makers' and 'shapers' of such policy. Even though accountability can be considered as "proving, in the most efficient manner, responsibility for the performance of certain results" (Kai, 2009, p. 40), academics in key management positions have mixed feelings about this accountability, i.e., they wish to retain their academic freedom and 'autonomy', but they do not oppose the idea of being evaluated by external agents, as long as overall quality improves (Ngwenya, 2003). This is consistent with the findings of Cardoso et al. (2013) and Watty (2006), who reported that quality assurance on many occasions is perceived as an excessive control that will affect their academic development, in such a way that academics sometimes adopt instrumental behaviors to circumvent the process.

In general, academics value accreditation as a moderately positive process, while managers evaluate it as very positive (Cardoso et al., 2013; Stensaker, Langfeldt, Harvey, Huisman, \& Westerheijden, 2011). To this end, Larrauri et al. (2012) reviewed 22 studies about quality management perceptions among academics and managers from nine countries, four of these having Spanish as official language, i.e., Argentina, Chile, Mexico, and Spain. They found that opinions 
328 PERCEPTIONS ABOUT ACCREDITATION AND QUALITY MANAGEMENT IN HIGHER EDUCATION. DEVELOPMENT OF A SPANISH-LANGUAGE QUESTIONNAIRE WITH A SAMPLE OF ACADEMICS FROM A PRIVATE UNIVERSITY - L. González-Bravo, D. Stanciu, N. Nistor, B. Castro, G. Puentes, M. Valdivia

differ depending on their position in HEIs: instructors in managerial positions are more willing to accept the rules imposed by quality assurance systems and more optimistic about the consequences of quality assurance programs within HEIs, than the non-managerial academic staff.

\section{Value of Accreditation to the Latin-American Educational System}

In South America, most findings show recognition among academics about positive effects of the quality assurance system, in terms of the value of higher education accountability (Vásquez, 2015). Zapata and Torre (2012) reported the results of a study with 16 universities from non-Anglo-Saxon countries showing greater progress in developing their QA systems: Mexico, Costa Rica, Colombia, Chile, Argentina, Portugal and Spain. They found that some of the positive effects of QA processes included change in the institutional QA framework, assessment of information for decision-making and a better relationship between the State and institutions.

One of the major goals of IPSOS (2010a, 2010b) was to provide the National Accreditation Commission of Chile (CNA) with information about the effects of institutional accreditation on HEIs. Its major findings included that participants pointed out the value of accreditation and CNA for the Chilean higher education system and as an opportunity for self-knowledge and learning for institutions.

Currently there is consensus in Latin America that quality assurance processes have had a real and significant impact on higher education institutions, contributing to the development of self-regulation instruments. Thus, its importance for universities today is fundamental and has a direct impact on the improvement of education in the different institutions (Lemaitre, 2019).

In 2019, CNA-Chile asked 711 institutional authorities and peer reviewers about their perceptions regarding the progress and challenges in these issues, in the context of improving the accreditation law. Among the multiple findings, they detected that mandatory integral accreditation for institutions was mentioned in 
the first place within the changes that will have a positive effect on institutions, and that the law will stimulate institutions to certainly improve their quality standards to better education for students (CNA-Chile, 2019).

In Latin America, Rresistance to change and to implementation of cultural changes in universities, has also been reported as an obstacle to the setting of a self-evaluation and accreditation process in Ecuador (Ayala Bolaños, 2018). Meanwhile, in Argentina, although there is recognition among university authorities that quality policies have contributed to the improvement of management, institutional transparency, and the incorporation of an evaluation culture, they express concern regarding an excessive bureaucratization of activities and reports, the risk of forced institutional homogenization or the lack of consistency in external evaluation reports (De Vincenzi, 2018).

\section{Roles of Peer Reviewers and State Guidelines}

The effectiveness of supervision, control or external support in accreditation processes is based on a broad participation of academics. At the same time, the standards that will be applied in the evaluation of the institution, although developed independently, must be based on consolidated national policies and applied independently of specific political interests or of third parties. The aforementioned elements allow HEIs to combine autonomy with responsibility and openness to the international environment (Lemaitre \& Anderson, 2010).

Less desirable aspects included criticism towards inconsistencies in the application of criteria, use of indicators, accuracy in decisions of accreditation, conflicts of interest, training and behavior of peer reviewers (Zapata $\&$ Torre, 2012), weak participation mechanisms, links between HE government policies and results of accreditation processes (Proyecto Alpha, 2011), and an absence of a deeper reflection in academics (Cardoso et al., 2013; Gregorutti \& Bon, 2012; Laughton, 2003; Lewis, 2016; Loukkola \& Zhang, 2010; Stensaker et al., 2011).

Although today the use of evaluation criteria and rubrics by peer reviewers is valued, inasmuch as it guarantees uniformity and 
330 PERCEPTIONS ABOUT ACCREDITATION AND QUALITY MANAGEMENT IN HIGHER EDUCATION. DEVELOPMENT OF A SPANISH-LANGUAGE QUESTIONNAIRE WITH A SAMPLE OF ACADEMICS FROM A PRIVATE UNIVERSITY - L. González-Bravo, D. Stanciu, N. Nistor, B. Castro, G. Puentes, M. Valdivia

transparency in peer judgments, there has been an overvaluation of formal aspects (De Vincenzi, 2018), displacing more substantial academic aspects to the background. Being able to develop a more substantial view would imply that they could not only act as auditors in management and accreditation processes, but also in those processes where they could speak as peers who express expert opinions that recognize the diversity of educational institutions and projects (Bernasconi, Fernández, Irarrázaval, Scharager, \& Villalón, 2020).

\section{Role of the Internal Quality Unit}

The departments in charge of quality processes in Chilean universities have a diversity of organizational forms and characteristics. For example, Venables and Van Gastel (2014) performed an analysis of three Chilean universities and pointed out that this diversity is due to the fact that these units carry out a work of "translation" and "generation of meaning" of the environmental regulations; these units are positively evaluated by academics and higher authorities, and are seen more as a unit of support rather than control (Venables \& Van Gastel, 2014). The units that have emphasized accountability, rather than the internal management of a culture of quality, tend to focus more on control, generating reactive systems to demands and compliance with external requirements (Scharager, 2017). Most of these units depend hierarchically on the top management level of the university or in close administrative proximity, and frequently they are part of an academic vice-chancellorship. In universities with less consolidated collegiate bodies, these units centralize more power, although in general they are well evaluated (Scharager, 2017). In fact, they have significant experience in different areas of higher education (Dooner, Armanet, Busco, d'Alencon, \& Salomone, 2016; Lemaitre et al., 2012; Scharager, 2017; Scharager \& Rodríguez Anaiz, 2019), and have become highly relevant for the accreditation and accountability of HEIs, being experts in different areas and transferring good practices, triggering reflection and institutional learning (Scharager, 2017; Venables \& Van Gastel, 2014). In the words of Campo Herrera (2018), they go slightly beyond their official role, providing "support and technical advice to Schools and Programs in areas related to self-assessment and curricular assessment processes, as well as teacher updating, skill assessment, 
virtual support for learning and its methodology, accreditation, among others" (p. 143).

\section{Student Participation}

Student participation in processes of accreditation and quality management is a well-valued and widespread practice (Lemaitre, 2019), but its true impact in the teaching-learning process is yet to be determined. Cardoso's (2009) research into two Portuguese HEIs found that while students evaluate the assessment of the institution positively, "appear in a position of maximum distance in relation to evaluation, both in socio-cognitive terms, and in terms of their 'practical' experience in the process" (p. 7). Part of this is because the students' educational experience has changed with more emerging demands (Volkwein et al., 2007).

The future of quality management should incorporate a greater participation of students with full interaction and learning among all levels (Westerheijden, Stensaker, Rosa, \& Corbett, 2014), which is not happening today due to structures of hierarchical and bureaucratic management and government (Cardoso et al., 2015; Martínez Iñiguez, Tobón Tobón, \& Romero Sandoval, 2017).

Recently in Chile and Colombia, research exploring student perceptions about quality has been published, where starting from accreditation standards, an acceptable, but absolutely satisfactory, perception about the quality of the educational service offered has been found (Vera-Millalén, 2018; Viloria-Escobar, Bertel-Narváez, \& Daza-Corredor, 2015). To explicitly consider the students' increasing demands has been reported as a key factor that promotes the culture of quality at the Institution, but raises some open questions. In the words of Lemaitre (2019) "How to activate and engage ordinary students in quality culture activities?” (p. 138).

\section{Continuous Quality Management}

The HE sector has been progressively implementing high quality management systems over the last two decades, with a substantial deliberation within academic institutions about the essence of 
332 PERCEPTIONS ABOUT ACCREDITATION AND QUALITY MANAGEMENT IN HIGHER EDUCATION. DEVELOPMENT OF A SPANISH-LANGUAGE QUESTIONNAIRE WITH A SAMPLE OF ACADEMICS FROM A PRIVATE UNIVERSITY - L. González-Bravo, D. Stanciu, N. Nistor, B. Castro, G. Puentes, M. Valdivia

such systems in higher education, and in an aggressive business environment which pushes HEIs to more complex, stable and permanent development (In'airat \& Kassem, 2014; Kauko, 2014; Trakman, 2008). The similarities and differences in quality concepts and organizational values were studied in the Netherlands by Kleijnen et al. (2011), who found that although these concepts and values were similar, effective departments had a more structured quality management commitment, closely linked to the daily work and its continuous improvement. That commitment with continuous improvement usually involves teamwork, and the first stage is gaining additional knowledge followed by a change of attitude, changing the relationship of each person and team with the surrounding environment (Taskov \& Mitreva, 2015).

In Latin America, quality processes and mechanisms described above are often implemented in many institutions, as a way of responding to external standards, rather than following a deep and full understanding of the culture of quality. The case of Chile is no exception, insofar as many of the improvements in quality were historically motivated by factors external to the legitimacy of the institutions, rather than the installation of a culture of quality (CIPERCHILE, 2012; Pedraja-Rejas \& Rodríguez-Ponce, 2015; Proyecto Alpha, 2011).

Quality management (QM) implies an improvement in quality as a whole (Dzimińska, Fijałkowska, \& Sułkowski, 2018), which includes the existence of internal and external evaluation processes, self-evaluation processes, progressive improvement, continuous monitoring of processes, resource management and the incorporation of remedial measures (Pulido-Roccatagliata \& Espinoza-Díaz, 2018). It also encompasses policies, concepts, approaches, ideas, systems and processes designed to guarantee the systematic maintenance and improvement of quality within an institution, having a more comprehensive character and deep connection with meaningful decision-making (Pratasavitskaya \& Stensaker, 2010). 


\section{Existing Specific Measurement Instruments}

We have reviewed the several English-language questionnaires to assess perceptions toward quality management and accreditation that have been developed over the past 40 years (Kleijnen et al., 2011; Larrauri et al., 2012). The Higher Education Survey, used by the New England Association of Schools \& Colleges (NEASC, 2006), has 25 items that assess perceived impact of accreditation processes inside an institution. The original survey questions were developed in conjunction with researchers outside NEASC, validating the robustness and validity of the questions, and then proceeding to a pretest before its final application (NEASC, 2006). Another example in the United States is the research developed by Schroeder (2008), who adapted the Quality Management Questionnaire of Grandzol and Gershon (1998).

In the Netherlands, Kleijnen et al. (2011), used a Quality Management Scale (QMA) to assess several aspects related to quality design and quality assurance (inspection, evaluation and improvement activities, involvement of faculty in quality management, and communication). In South Africa, Ngwenya (2003) proposed a survey oriented to exploring quality assurance in South African Higher Education and its implementation at the University of Durban-Westville (UDW). Besides biographical data, the questionnaire consists of 11 closed items and two open questions. The questionnaire includes reviews of concepts and definitions of quality, the importance of institutional self-evaluation and external audits, the relationship between quality and academic development, relationships between national and institutional quality policy, the implementation of quality assurance mechanisms in UDW, personal quality and team development, management familiarity with relevant legislation and policies, the evaluation of academic programs by students and other issues considered important by respondents.

To summarize, we identified and analyzed the most relevant studies, with the overarching purpose of developing and validating a Spanish-language scale which assesses perceptions about the accreditation process and quality management in Higher Education 
334 PERCEPTIONS ABOUT ACCREDITATION AND QUALITY MANAGEMENT IN HIGHER EDUCATION. DEVELOPMENT OF A SPANISH-LANGUAGE QUESTIONNAIRE WITH A SAMPLE OF ACADEMICS FROM A PRIVATE UNIVERSITY - L. González-Bravo, D. Stanciu, N. Nistor, B. Castro, G. Puentes, M. Valdivia

Institutions. Our literature review led to the identification of six core areas present in the quality $\&$ accreditation perceptions: benefits of accreditation, value of accreditation to the Latin-American educational system, peer-reviewers' roles and state guidelines, value of the internal quality unit, student participation and continuous quality management. Therefore, our main research question was whether or not the same main factors that transpired from our literary review can be isolated in our research. Consequently, the corresponding working hypothesis was that we would find all these factors in the structure of our model.

\section{Methodology}

\section{Research Design}

A one-time, cross-sectional research design was utilized in order to identify relevant association between the variables of interest (main scale constructs corresponding to hypothesized subscales) and their contribution to the perception regarding the accreditation process.

\section{Participants}

The research targeted a private University's personnel without managerial positions, from four Chilean cities (Concepción, Puerto Montt, Santiago and Valdivia), which made up a population of 4,679 individuals. For the current study, a purposive, convenience research sample, totaling 339 persons, was drawn from this larger population. The mean age of our sample was $M=40.98$ years, standard deviation $S D=11.50 .198(58.41 \%)$ participants were females, with mean age $M=40.03$ years, $S D=11.34 ; 134(39.53 \%)$ were males, with mean age $M=42.40$ years, $S D=11.63$; and $7(2.06 \%)$, refused to declare their gender and age. 161 (47.49\%) participants were tenured faculty members, with mean age $M=41.55$ years, $S D=13.19$; 168 (49.45\%) were part-time faculty, with mean age $M=40.57$ years, $S D=9.57$, and $10(2.95 \%)$ participants did not declare their employment status, mean age $M=33.67$ years, $S D=5.51$.

The purposive sampling including academics from several University campuses, without management positions, is pertinent 
when considering the antecedents previously presented in the theoretical framework regarding the comparison with managers' perceptions (Cardoso et al., 2013; Stensaker et al., 2011), and potential geographic differences. A purposive, convenience research sample, as a complementary sequential stage of a measure validation, has been previously reported by Milne, Creedy, and West (2016) and Fernandez, Omar, and Husain (2013) with positive results, and even in the study of Carpio et al. (1999) considering Chilean and Canadian samples.

\section{Data Collection Procedure}

Faculty academic personnel were sent invitations by their corresponding University Program Directors, for each city. The invitations informed participants about the objectives of the study, confidentiality of data processing, and contact data of researchers. In addition, participants were informed that their participation was voluntary, i.e., did not imply any financial or other type of reward, considering an Informed Consent in order to accept to participate in the research. Finally, paper printed questionnaires were sent via regular mail to participants in the four Chilean cities with the aid of Program secretaries in each campus.

\section{Data Analysis}

The collected data was subject to a preprocessing procedure consisting of cleaning and preparation (e.g., coding, reversing inverted/ negatively formulated items, missing cases and outlier analyses) for specific data analyses. After preprocessing, an exploratory factor analysis (EFA) and a consequent confirmatory factor analysis (CFA) led to the final models.

Factor analysis, both exploratory and confirmatory, is regularly used in the social sciences for the creation or validation of instruments, insofar as they allow researchers to determine which theoretical constructs underlie a given set of data and the extent to which these constructs represent the original variables (Henson \& Roberts, 2016). On one hand, exploratory factor analysis (EFA) explores the data and provides guidance from the factor number through to identifying 
336 PERCEPTIONS ABOUT ACCREDITATION AND QUALITY MANAGEMENT IN HIGHER EDUCATION. DEVELOPMENT OF A SPANISH-LANGUAGE QUESTIONNAIRE WITH A SAMPLE OF ACADEMICS FROM A PRIVATE UNIVERSITY - L. González-Bravo, D. Stanciu, N. Nistor, B. Castro, G. Puentes, M. Valdivia

correlations among observable variables (Carpenter, 2018). The confirmatory factor analysis, on the other hand, allows the researchers to test the hypotheses about the relationship between indicators and latent dimensions, detected through the EFA (Batista-Foguet, Coenders, \& Alonso, 2004; Carpenter, 2018).

The aforementioned applies to Likert-type scale items, to operationalize unobserved constructs (Li, 2016). Because data from surveys are often on an ordinal level, and sometimes slightly nonnormally distributed, it is suggested to use estimators that are robust against nonnormality, such as maximum-likelihood (ML). This was the main estimation method used for this research, for both the EFA and the CFA (Babyak \& Green, 2010; Knekta, Runyon, \& Eddy, 2019; Li, 2016).

Particularly in the EFA case, previous studies have reported that EFA conducted on Likert scales' items, could produce an overinflated number of factors (Alexis Dinno, 2009; Glorfeld, 1995). In addition, specific research concerning the differences in factor solutions between interval and ordinal data, suggest that polychoric correlations may provide a more accurate reproduction of the observed data (Holgado-Tello, Chacón-Moscoso, Barbero-García, $\&$ Vila-Abad, 2008). For this reason, the polychoric correlations alternative was additionally employed in the factor analysis provided by R's psych package (Revelle, 2018).

\section{Data Preprocessing and Preparation}

The collected data was processed using IBM ${ }^{\mathrm{TM}}$ SPSS (IBM, 2016) version 24, and IBM AMOSTM (Arbuckle, 2014). Almost all computations were replicated using the R Statistical Computing Software (R Core Team, 2017). Missing data was verified for patterns of missingness and for participants' lack of engagement and that no cases of missing data were identified. However, the multivariate outlier's analysis using the Mahalanobis distance identified 29 cases of outliers that were excluded from the records used in developing the models. A further inspection of these outliers revealed that they were the results of unengaged responding, i.e., respondents whose 
patterns of responses were straight-lined and/or otherwise aberrant, and, as such, potentially indicative for disengaging from honest and thoughtful responding. Consequently, these respondents were not considered further in the analyses.

\section{Scale Development}

Initial measures.

Four existing questionnaires, utilized in previous studies with similar interests, were considered as sources for the questionnaire developed in our research, and the list of items whose content was adapted to Chilean culture and quality assurance system were extracted from them. Four academics who have participated in leading accreditation processes agreed upon the conceptual and content relevance and the phrasing of items, and a final 38 item (question) inventory was built.

Higher Education Survey (NEASC, 2006). This scale included 25 items measured on a 5-point Likert Scale. NEASC (2006) applied it originally to 21 respondents representing higher education public institutions and 14 respondents from higher education independent institutions, but no reliability scores were reported.

Quality assurance in South African Higher Education (QAS). Implemented at the University of Durban-Westville (Ngwenya, 2003), the questionnaire consisted of 11 closed items (Likert: Five Points, from Strongly agree to Strongly disagree). Originally applied to 24 managers, no factor structure or reliability score were reported.

Quality Management Questionnaire (QMC). The scale is a 62item, six-point Likert scale, ranging from strongly disagree to strongly agree (Grandzol \& Gershon, 1998). It was applied originally to 275 suppliers of the US armed forces (Grandzol \& Gershon, 1998; Schroeder, 2008). The reported reliability scores were 0.87 for customer focus, 0.84 for cooperation, 0.82 for process management, 0.81 for learning, 0.75 for continuous improvement, 0.74 for employee fulfillment, and 0.73 for leadership. 
338 PERCEPTIONS ABOUT ACCREDITATION AND QUALITY MANAGEMENT IN HIGHER EDUCATION. DEVELOPMENT OF A SPANISH-LANGUAGE QUESTIONNAIRE WITH A SAMPLE OF ACADEMICS FROM A PRIVATE UNIVERSITY - L. González-Bravo, D. Stanciu, N. Nistor, B. Castro, G. Puentes, M. Valdivia

The Quality Management Activities Scale (QMA). This scale consisted of 16-items on a five-point Likert scale, from fully disagree to fully agree, and was separated into three subscales. The reliability scores (Cronbach's alpha) reported in the original study for each subscale were 0.89 for the PDCA cycle, 0.84 for the external evaluation and communication subscale, and 0.73 for the internal evaluation and communication, while the reported reliability score for the entire scale was 0.93 . This scale was originally applied to 266 respondents in the Netherland's Higher Education System (Kleijnen et al., 2011).

The instrument employed.

A composite of 38-item, 5 point Likert scale, ranging from strongly disagree to strongly agree was built by incorporating a) 23 items (items 1 to 23) taken from the Higher Education Survey (NEASC, 2006), b) 10 items (24 to 33) from the Quality Assurance in South African Higher Education scale (Ngwenya, 2003), c) four items (34 to 37) from the Quality Management Questionnaire (Grandzol \& Gershon, 1998; Schroeder, 2008) and, lastly, d) a single item (item 38) from the Quality Management Activities Scale (Kleijnen et al., 2011).

This 38-item scale was translated into Spanish using a stepwise protocol developed by the research team and based on previous research (Arnau, Martinez, Niño de Guzmán, Herth, \& Yoshiyuki Konishi, 2010; Collazo, 2005; Ruiz, Berrocal, López, \& Rivas, 2002):

a) A first integral translation from English to Spanish based on the original sources was performed by a university professor of English who had no affiliation with the research team (Version S1).

b) This first version was revised in terms of content by all authors, and, consequently, was sent to the University Ethics Committee (Version S2).

c) The version already approved by University Ethics Committee (Version S2E), was translated back into English language by a translator to analyze its concordance with the original version.

d) Finally, it was compared to the Spanish version and approved by two independent bilingual academics. 


\section{Results}

\section{Model Development}

Exploratory factor analysis.

Both the parallel factor analysis conducted using an SPSS syntax developed by Fabrigar and Wegener (2012), and replication of this parallel analysis using the online parallel analysis engine developed by Patil, Surendra, Sanjay, and Donavan (2007), indicated a 4-factor solution. However, another parallel analysis conducted in R (R Core Team, 2017) using Dinno's (2012) paran package and replicating the same analysis with the R's psych package (Revelle, 2018), indicated a 7 to 10 factor solution. Another EFA using Maximum Likelihood (ML) indicated a substantially different 10 -factor solution based on eigenvalues greater than 1.0 .

Alternative polychoric correlations in the factor analysis provided by the R's psych package (Revelle, 2018) were employed and suggested 4 components and 6 common factors (see Figure 1 and Table 1 for the graphical solution and, respectively, for the EFA results).

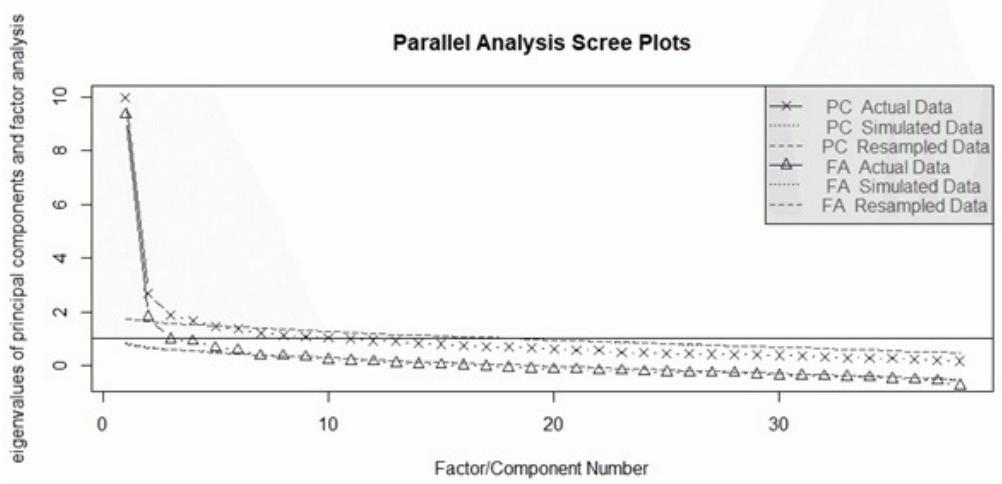

Figure 1: Parallel analysis using the polychoric correlations (Revelle, 2018) indicating 4 components, and, respectively, 6 common factors 
340 PERCEPTIONS ABOUT ACCREDITATION AND QUALITY MANAGEMENT IN HIGHER EDUCATION. DEVELOPMENT OF A SPANISH-LANGUAGE QUESTIONNAIRE WITH A SAMPLE OF ACADEMICS FROM A PRIVATE UNIVERSITY - L. González-Bravo, D. Stanciu, N. Nistor, B. Castro, G. Puentes, M. Valdivia

Table 1.

Pattern matrix generated by EFA

\begin{tabular}{lcccc}
\hline \multicolumn{5}{c}{ Factor } \\
\hline Item & A & B & C & D \\
\hline it2_HES2 & 0.855 & & & \\
\hline it5_HES5 & 0.78 & & & \\
\hline it4_HES4 & 0.779 & & & \\
\hline it1_HES1 & 0.738 & & & \\
\hline it3_HES3 & 0.62 & & & \\
\hline it10_HES10 & & 0.862 & & \\
\hline it18_HES18 & & 0.611 & & \\
\hline it9_HES9 & & 0.578 & & \\
\hline it19_HES19 & & & \\
\hline it29_QAS6 & & & & \\
\hline it28_QAS5 & & & & \\
\hline it31_QAS8 & & & & \\
\hline it21_HES21 & & & \\
\hline it22_HES22 & & & & \\
\hline
\end{tabular}

The inspection of variance explained, the extracted communalities, and the pattern matrix of EFA using Maximum Likelihood as the common factor analysis, with both Promax and Direct Oblimin rotations, revealed that the cumulative contribution of the extracted factors to the cumulative variance had a rather uniform rate of descent.

Problematic items were removed following an iterative process that considered the severity and overlapping of problems that they pose for a clean solution. The first criterion that we considered was to keep the explained variance to the maximum possible, by first eliminating the items that did not load on any factors during EFA using ML with Promax rotation, without constraining or forcing a smaller number of items than those automatically selected by the algorithm based on eigenvalues.

A four-factor solution resulted from the iterative EFA, during which 24 items were eliminated based on the above-mentioned criteria. This solution explained $55.49 \%$ of the variance in data. The 
sampling adequacy was meritorious, as measured with the KaiserMeyer-Olkin test of .86 (Kaiser, 1970, 1974).

Confirmatory factor analysis.

Based on the results from the EFA presented above, a 4-factor model was built and tested with IBM SPSS AMOS ver. 24. Factor A (Institutional relevance of accreditation) included loadings from scales assessing facets of positive effects of accreditation on the university. Factor B (Objectivity of accreditation evaluation) included loadings from items that assess clarity, quality and completeness of functions and support from the national accreditation commission and peer reviewers. Factor C (Internal Quality Unit relevance for accreditation) is associated with items that assess value and functions of the internal quality unit, within the organization. Finally, Factor D (Value of accreditation to educational system), expands the scope outside the university, towards the educational system as a whole, evaluating the value of accreditation for the system mentioned.

The model had good to very good indices of fit, e.g., NFI =.947, PCLOSE $=.684, R M R=.023$, RMSEA $=.045$, SRMR $=.036$. Fit indices are presented in more detail in Table 4.

Nevertheless, the model had slight discriminatory and convergent validity risks associated with factor B, whose maximum shared variance was slightly higher than the average variance extracted (.55 vs. .46).

Because the initial analyses regarding the suggested number of factors indicated between four and six factors, we conducted a series of separate EFA's on the excluded items and identified two factors which could be included in the initial four-factor model. Consequently, these two alternative models were considered for further confirmatory factor analysis using IBM SPSS AMOS TM ver. 25. These two additional factors (E \& F) are related to "Continuous Quality Management value" and to "Student participation value", respectively. 
342 PERCEPTIONS ABOUT ACCREDITATION AND QUALITY MANAGEMENT IN HIGHER EDUCATION. DEVELOPMENT OF A SPANISH-LANGUAGE QUESTIONNAIRE WITH A SAMPLE OF ACADEMICS FROM A PRIVATE UNIVERSITY - L. González-Bravo, D. Stanciu, N. Nistor, B. Castro, G. Puentes, M. Valdivia

The 6-factor model also had good fit indices, e.g., NFI = .931, PCLOSE $=.899$, RMR $=.027$, RMSEA $=.041$, SRMR $=.037$.

However, the discriminant and validity issue grew and affected also factors A (a maximum shared variance of .76 vs. an average variance extracted of .60) and $\mathrm{E}$ (maximum shared variance of .76 vs. an average shared variance of .45), along with B's validity concerns, inherited from the 4-factor model. The indices for reliability and validity are presented in detail in Table 2 .

Table 2.

Indices of reliability and discriminant and convergent validity

\begin{tabular}{|c|c|c|c|c|c|c|c|c|c|c|c|c|}
\hline Model & Factor & alpha & $C R$ & AVE & MSV & SQRT(AVE) & \multicolumn{6}{|c|}{ Inter-factor correlations } \\
\hline & & & & & & & A & B & C & $\mathrm{D}$ & $E$ & $\mathrm{~F}$ \\
\hline \multirow[t]{2}{*}{ A } & $4 \mathrm{~F}$ & 0.88 & 0.88 & 0.59 & 0.55 & 0.77 & - & & & & & \\
\hline & $6 \mathrm{~F}$ & & 0.88 & 0.60 & $0.76^{*}$ & $0.77^{*}$ & - & & & & & \\
\hline \multirow[t]{2}{*}{ B } & $4 \mathrm{~F}$ & 0.69 & 0.71 & 0.46 & $0.55^{*}$ & $0.68^{*}$ & 0.74 & - & & & & \\
\hline & $6 \mathrm{~F}$ & & 0.71 & 0.46 & $0.63 *$ & $0.68 *$ & 0.74 & - & & & & \\
\hline \multirow[t]{2}{*}{ C } & $4 \mathrm{~F}$ & 0.75 & 0.76 & 0.51 & 0.15 & 0.71 & 0.39 & 0.34 & - & & & \\
\hline & $6 \mathrm{~F}$ & & 0.76 & 0.51 & 0.25 & 0.71 & 0.39 & 0.34 & - & & & \\
\hline \multirow[t]{2}{*}{$\mathrm{D}$} & $4 \mathrm{~F}$ & 0.77 & 0.78 & 0.64 & 0.45 & 0.80 & 0.67 & 0.60 & 0.38 & - & & \\
\hline & $6 \mathrm{~F}$ & & 0.78 & 0.64 & 0.52 & 0.80 & 0.67 & 0.60 & 0.38 & - & & \\
\hline$E$ & $6 \mathrm{~F}$ & 0.71 & 0.71 & 0.45 & $0.76^{*}$ & $0.67^{*}$ & 0.87 & 0.79 & 0.50 & 0.72 & - & \\
\hline $\mathrm{F}$ & $6 \mathrm{~F}$ & 0.88 & 0.89 & 0.79 & 0.14 & 0.89 & 0.17 & 0.17 & 0.38 & 0.17 & 0.32 & - \\
\hline
\end{tabular}

Note: Alpha is Cronbach's alpha; CR is composite reliability; AVE is average variance extracted; MSV is maximum shared variance; $A S V$ is average shared variance. The starred indices suggest possible risks of discriminant or, respectively, convergent validity.

Both the 4-factor and the 6-factor models are depicted in Figures 2 and, respectively, 3. The item loadings for the four and sixfactor models are presented in Table 3. The fit indices of 4-factor and six-factor solutions are showed in Table 4. The items' coding preserve the acronyms from original sources, i.e., HES (NEASC, 2006), QAS (Ngwenya, 2003), QMA (Kleijnen et al., 2011) and QMQ (Schroeder, 2008). 


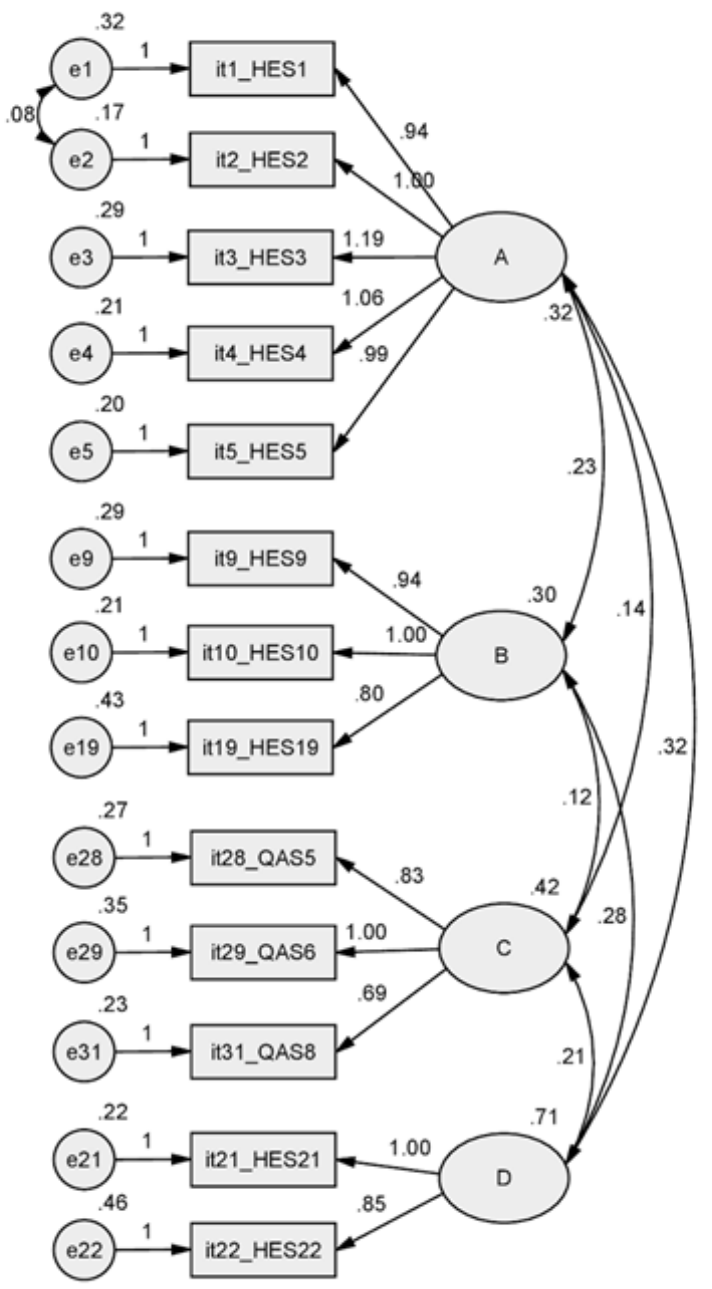

Figure 2.

The four-factor model. The factors are A) Institutional relevance of accreditation, B) Objectivity of accreditation evaluation, C) Internal Quality Unit relevance for accreditation, and D) Value of accreditation to educational system 
344 PERCEPTIONS ABOUT ACCREDITATION AND QUALITY MANAGEMENT IN HIGHER EDUCATION. DEVELOPMENT OF A SPANISH-LANGUAGE QUESTIONNAIRE WITH A SAMPLE OF ACADEMICS FROM A PRIVATE UNIVERSITY - L. González-Bravo, D. Stanciu, N. Nistor, B. Castro, G. Puentes, M. Valdivia

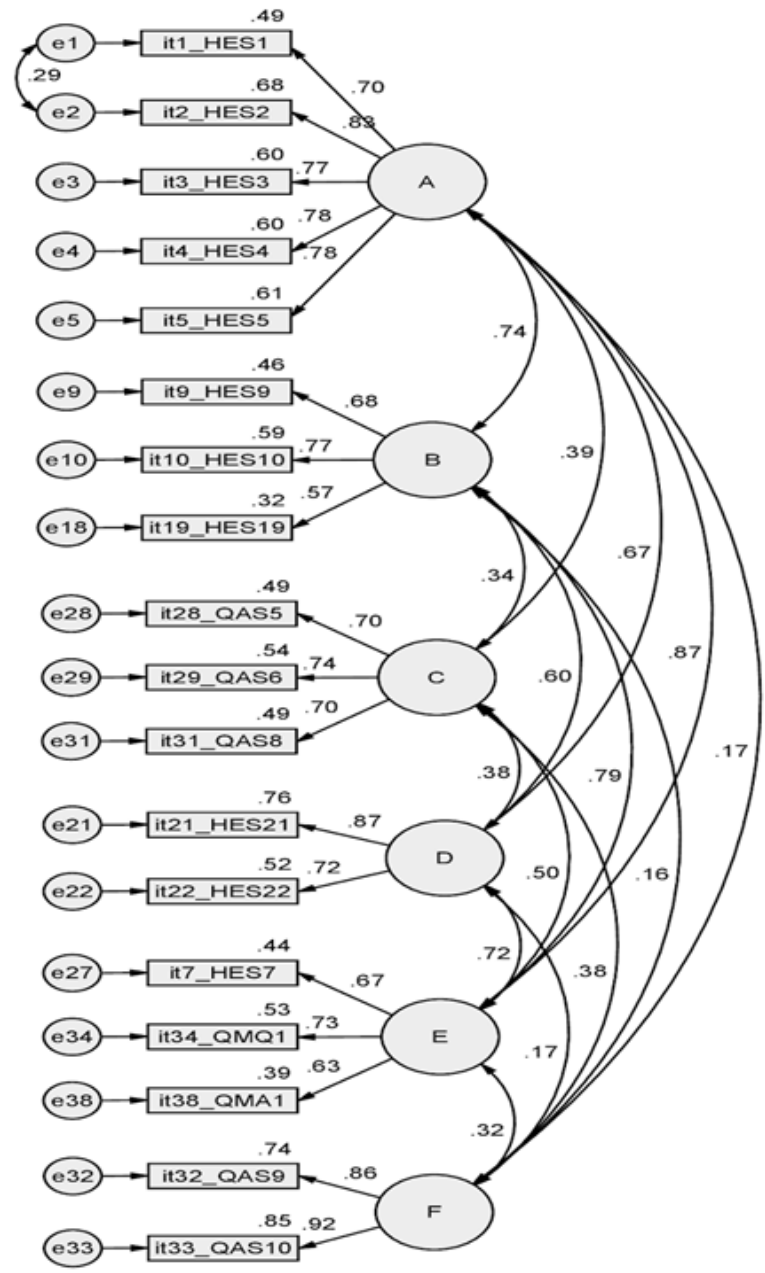

Figure 3.

The six-factor model. In addition to factors A through D, factors E, Continuous Quality Management Value, and F, Student Participation Value, respectively, were added to the four-factor model 
Table 3.

Item loadings for the two models

\begin{tabular}{cccc}
\hline \multirow{3}{*}{ Factor } & & \multicolumn{2}{c}{ Weight } \\
\cline { 2 - 4 } A & Item & 4-factor & 6-factor \\
\cline { 2 - 4 } & it1_HES1 & 0.685 & 0.699 \\
\cline { 2 - 4 } & it2_HES2 & 0.809 & 0.825 \\
\cline { 2 - 4 } & it3_HES3 & 0.781 & 0.772 \\
\cline { 2 - 4 } & it4_HES4 & 0.794 & 0.777 \\
\hline \multirow{2}{*}{ B } & it5_HES5 & 0.777 & 0.781 \\
\cline { 2 - 4 } & it9_HES9 & 0.689 & 0.678 \\
\cline { 2 - 4 } & it10_HES10 & 0.766 & 0.769 \\
\hline C & it19_HES19 & 0.556 & 0.566 \\
\cline { 2 - 4 } & it28_QAS5 & 0.718 & 0.702 \\
\cline { 2 - 4 } & it29_QAS6 & 0.741 & 0.738 \\
\hline D & it31_QAS8 & 0.679 & 0.699 \\
\cline { 2 - 4 } & it21_HES21 & 0.872 & 0.873 \\
\hline E & it22_HES22 & 0.725 & 0.724 \\
\cline { 2 - 4 } & it7_HES7 & & 0.665 \\
\cline { 2 - 4 } & it34_QMQ1 & & 0.726 \\
\cline { 2 - 4 } & it38_QMA1 & & 0.626 \\
\hline F & it32_QAS9 & & 0.920 \\
\cline { 2 - 4 } & it33_QAS10 & \\
\hline
\end{tabular}

Table 4

Fit indices of 4-factor and 6-factor solutions

\begin{tabular}{lccccccccc}
\hline Model & CMIN & RMR & GFI & NFI & RFI & CFI & RMSEA & PCLOSE & $\begin{array}{c}\text { Standardized } \\
\text { RMR }\end{array}$ \\
\hline 4F Model & 1.620 & .023 & .957 & .947 & .928 & .979 & .045 & .684 & .0364 \\
\hline 6F Model & 1.514 & .027 & .941 & .931 & .912 & .975 & .041 & .899 & .0374 \\
\hline
\end{tabular}

Note. CMIN: ratio of the chi-square statistic over degrees of freedom, RMR: root mean square residual, GFI: Goodness of Fit Index, NFI: Normed Fit Index, RFI: relative fit index, CFI: comparative fit index, RMSEA, root mean square error of approximation, PCLOSE: $p$ value for testing the null hypothesis that RMSEA is less than .05, RMR: root mean square residual.

The Chi-square tests performed for models and its pathways, indicated that both final 4-factor and 6-factor models are invariant across gender and job type. It is necessary to mention that item 18 (it18_HES18), initially considered in both models, was later excluded to obtain configural invariance across job type (tenured vs. part-time). 
346 PERCEPTIONS ABOUT ACCREDITATION AND QUALITY MANAGEMENT IN HIGHER EDUCATION. DEVELOPMENT OF A SPANISH-LANGUAGE QUESTIONNAIRE WITH A SAMPLE OF ACADEMICS FROM A PRIVATE UNIVERSITY - L. González-Bravo, D. Stanciu, N. Nistor, B. Castro, G. Puentes, M. Valdivia

\section{Discussion and Conclusions}

The present research aimed to build a scale regarding faculty perceptions with respect to accreditation and quality management processes in Latin-American HEIs that have recently been through an accreditation process following the structure that combines self-evaluation, external peer evaluation and use of performance indicators (Ganga Contreras, 2016). Thus, our research achieved its main objective, i.e., the construction of a feasible multidimensional measurement instrument, and has responded positively to its research question, finding factors present in previous instruments or in our literary review.

We used structural equation modeling and identified two models, with appropriate fit indices, that could underpin the phenomenon addressed. The first one, a 4-factor structure, includes factors A, Institutional relevance of accreditation, B, Objectivity of accreditation evaluation, C, Internal Quality Unit relevance for accreditation, and D, Value of accreditation to educational system, whereas the second, 6-factor model, includes factors E, Continuous quality management value, and F, Student participation value.

From a more descriptive or idiographic perspective, the results parallel the characteristics of the accreditation process and the level of increasing evolution of quality assurance systems as a whole (Zapata $\&$ Torre, 2012). In our research, greater factor loadings were found in items which assess institutional relevance of accreditation. This is consistent with the consensus that exists in Latin America about the value of accreditation for institutions (Lemaitre, 2019), which is also regularly verified in Chile (CNA-Chile, 2019) and complementary, this is not surprising, since self-assessment itself is an opportunity to generate virtuous quality cycles inside the institution, with a wide participation of several actors.

The other three factors found - and their meanings - are related to previous literature. The value of objectivity of the accreditation evaluation is clearly present as a factor in the adjusted scale, related with the experience of peer review committee, and the training to 
prepare for an accreditation visit. In Chile, in the study made by IPSOS (2010a, 2010b) for the CNA, the participants pointed out the value of accreditation for the Chilean higher education system, as an opportunity for self-knowledge and learning for institutions. The importance of quality assurance as a whole can also be seen in Zapata and Torre's (2012) study, conducted in several Latin-American countries, and in those studies that have found in Chile a critical position about inconsistencies in the application of criteria, use of indicators, rigor in decisions about accreditation, conflicts of interest, training and practices of peer reviewers, among others, which is consistent with recent assertions of Bernasconi et al. (2020) regarding the Chilean context, and De Vincenzi (2018) or Aguilera (2017), in relation to Argentina.

With respect to the factor Value of accreditation to educational system, as noted by IPSOS (2010a, 2010b) and Dooner et al. (2016), among others, the main positive effects of accreditation are observed in institutional management improvement, undergraduate teaching program offers, teaching processes, graduate follow-up and research. The relationship that must exist between the HEI quality assurance systems and those of the environment should be understood by integrating the approaches of Toro (2012) and Mizikaci (2006): a HEI as a dynamic system with multiple interactions within itself and the environment, where accountability and quality assurance function as a linking element.

Regarding the Internal Quality Unit relevance for accreditation, the quality assurance unit and its functions performed within the university fulfill a central role in the perception of accreditation and quality inside the institution (Campo Herrera, 2018; Scharager, 2017; Scharager \& Rodríguez Anaiz, 2019; Venables \& Van Gastel, 2014). This is due to, on one hand, to the role it plays leading accreditation processes of programs and the institution, and, on the other hand, to the fact that the quality processes are still a way of responding to external standards, rather than a full incorporation of quality culture in each HEI level (CIPER-CHILE, 2012; De Vincenzi, 2013; González-Bravo et al., 2019; Pedraja-Rejas \& Rodríguez-Ponce, 2015; Proyecto Alpha, 2011). It follows that it is important to replicate this 
348 PERCEPTIONS ABOUT ACCREDITATION AND QUALITY MANAGEMENT IN HIGHER EDUCATION. DEVELOPMENT OF A SPANISH-LANGUAGE QUESTIONNAIRE WITH A SAMPLE OF ACADEMICS FROM A PRIVATE UNIVERSITY - L. González-Bravo, D. Stanciu, N. Nistor, B. Castro, G. Puentes, M. Valdivia

study or apply this measure to other institutions, with other forms of participation of academics (Scharager, 2017), evaluating whether the same factorial structure is observed. This is consistent with a weak correlation observed between the value of the internal quality unit and other factors. A potential influencing factor for our finding may be that, while its official function is the promotion of quality, its creation concentrated central responsibilities associated with the quality in the organization, leaving a lesser sense of ownership in academics (Cardoso et al., 2018).

The second solution, with an underlying six-factor structure, contains two additional factors, i.e., Continuous Quality Management value and Students' participation value. Particularly for Chile, where the scale was validated, although the incorporation of the quality dimension in internal processes in HEIs is recognized as essential to achieve sustained and adequate quality standards and sustainability for the organization (Cárdenas \& García, 2014), it has undergone a slow process and its results are yet to be definite. More specifically, Chile has not yet fully moved on from an accountability focused QA culture, into a culture of QM understood as a permanent process. Many institutions implement mechanisms of quality assurance as a response to external standards, rather than a quality culture implementation (González-Bravo et al., 2019). Additionally, this drawback can be associated with a political component, inasmuch as public controversy has raised questions of the legitimacy of organizations and their activity, resulting in shut-down HEIs, corruption allegations, etc. Paradoxically, however, unless HEIs install QM mechanisms in their internal processes, no systemic and consistent improvement can be expected.

With respect to factor F, students' participation value, this is a widespread practice in Chilean universities, largely stimulated by accreditation processes (Salazar, 2008). However, it is necessary to widen the scope of these evaluations, since there are differences among institutions in various areas related to it: performance evaluation policy, impact on the academic program, feedback to academics, etc. (Salazar, 2008). The fact that there is a weak correlation between this factor and the others in the questionnaire may be due to what 
was reported by Cardoso et al. (2018), regarding the cognitive and experiential distance in the students, towards the actions of quality in the University. As was mentioned in the theoretical framework, in the words of Lemaitre (2019), it remains a pending task how to meaningfully involve students in quality activities.

The Chilean higher education system has experienced a significant maturation in recent years and the quality assurance system has had a significant impact, ensuring an orderly growth and better guarantees for users. Nowadays in Chile, in the media and in major institutional stakeholders, the importance of HEI and program accreditation has been increasingly recognized, both to operationalize the standards which guide the strategic development of the country, and to eliminate suboptimal practices in educational management. Due to the diversity that exists within educational institutions and differing degrees of knowledge that different members of HEIs have regarding accreditation and quality management, we suggest that further scientific studies apply the measure developed in this article among other groups (for example, managers or students), or to several public universities. These results could be analyzed also from previous research that report differences in perceptions associated with different positions inside an organization or personal characteristics. That is the case of planning, learning value, knowledge about organization resources, importance of accreditation for the country, among others (Grubisic \& Kovacevic, 2010; Kleijnen, 2012; Kruempel, 1990).

The instrument developed in this research presents adequate psychometric properties and factor structure, is conceptually and theoretically coherent with the state of the art in the field of quality management in Latin America, which are better than those developed previously in Latin America in prior research (Busco et al., 2018; Gregorutti \& Bon, 2012; IPSOS, 2010a, 2010b; Lemaitre et al., 2012; Zapata $\&$ Torre, 2012) and in many ways, even with respect to others developed in the world, which even often do not report adequate antecedents such as internal consistency (NEASC, 2006; Putnam, 2000). In terms of the thoroughness and completeness of the background information delivered, it is comparable to that 
350 PERCEPTIONS ABOUT ACCREDITATION AND QUALITY MANAGEMENT IN HIGHER EDUCATION. DEVELOPMENT OF A SPANISH-LANGUAGE QUESTIONNAIRE WITH A SAMPLE OF ACADEMICS FROM A PRIVATE UNIVERSITY - L. González-Bravo, D. Stanciu, N. Nistor, B. Castro, G. Puentes, M. Valdivia

reported by Kleijnen et al. (2011), and is therefore a contribution to international knowledge about perceptions of HEI members regarding quality management and accreditation.

Our study's limitations include: 1) Non-random sampling (the participating academic staff agreed to participate based on an invitation made by their units' directors). Nevertheless, the researchers did not select intentionally, or 'handpick' the participants, and their participation was neither coerced nor rewarded in any way. 2) The exploratory and confirmatory factor analyses performed during this research are entirely replicable and their results outperform those of the original measures on which the questionnaire was based. 3) The original measures were developed in research carried out outside Latin America, which can raise doubts as to the meaning of the constructs in different languages. The aspect pertaining to adaption from English to Spanish was controlled by using translators and academics with accreditation experience, which made the necessary modifications before the application. 4) The study was conducted in a private Chilean University, and it is necessary to replicate these findings including other types of higher education settings (e.g. technical, public or traditional universities), considering the differences between public and private institutions reported by literature (Muñoz, 2016). 5) A vast majority of the previous research, identified during our literature review, derives from doctoral studies. From our perspective, rather than being a weakness, it is a reiteration of the need for more studies regarding the perceptions about accreditation and quality, as an emerging field within research in the quality of higher education (Cardoso et al., 2013). Lafont (2014) offers a complementary view in this regard, from the field of education. Doctoral students choose the topics of their theses considering the circumstances that motivated them to enroll, as well as their trajectory as beginning researchers and the social use that they want to give to their thesis, when it is finished. This makes it possible to explain why theses regarding perceptions about quality (and its specific value), must also be analyzed from researchers who investigate emerging requirements in their countries of origin: this is the case of Scharager (2017), Ngwenya (2003) or Cardoso (2009). 
There is a growing commitment to accountability and an increasing expectation of installing a culture of quality within institutions. Therefore, the availability of a Spanish-language measure that can feasibly assess the perceptions about accreditation/quality management, has a direct impact on the development of the area. For example, the state of development of an institution could be evaluated over long periods of time, or through comparing different countries or types of institution (public versus private).

Finally, despite the limitations of this research that were discussed above, the development and dissemination of this instrument has the potential to bring a concrete and timely contribution to higher education in Latin-American countries and for the body of knowledge pertaining to educational research and management.

\section{References}

Aguilera, R. (2017). Aseguramiento de la calidad de la educación superior. Educación Superior y Sociedad (ESS), 22(22), 131-154.

Arbuckle, J. L. (2014). Amos (Version 23.0) [Computer Program]. Chicago: IBM SPSS.

Arnau, R. C., Martinez, P., Niño de Guzmán, I., Herth, K., \& Yoshiyuki Konishi, C. (2010). A Spanish-Language Version of the Herth Hope Scale: Development and Psychometric Evaluation in a Peruvian Sample. Educational and Psychological Measurement, 70(5), 808-824. https://doi.org/10.1177/0013164409355701

Ayala Bolaños, M. (2018). La Gestión de la Autoevaluación como variable para el aseguramiento de la Calidad de la Educación Superior en el Ecuador. "Carácter" Revista Científica de la Universidad Del Pacifico, 6(1)

Babyak, M. A., \& Green, S. B. (2010). Confirmatory Factor Analysis: An Introduction for Psychosomatic Medicine Researchers. Psychosomatic Medicine, 72(6), 587-597. https://doi.org/10.1097/ PSY.0b013e3181de3f8a

Batista-Foguet, J. M., Coenders, G., \& Alonso, J. (2004). Análisis factorial confirmatorio. Su utilidad en la validación de cuestionarios relacionados con la salud. Medicina clínica, 122(1), 21-27. 
352 PERCEPTIONS ABOUT ACCREDITATION AND QUALITY MANAGEMENT IN HIGHER EDUCATION. DEVELOPMENT OF A SPANISH-LANGUAGE QUESTIONNAIRE WITH A SAMPLE OF ACADEMICS FROM A PRIVATE UNIVERSITY - L. González-Bravo, D. Stanciu, N. Nistor, B. Castro, G. Puentes, M. Valdivia

Bernasconi, A., Fernández, E., Irarrázaval, I., Scharager, J., \& Villalón, M. (2020). Aseguramiento de la calidad y la nueva Ley de Educación Superior. Temas de la Agenda Pública, 15(125), 1-14.

Busco, C., Dooner, C., \& d'Alencon, A. (2018). Universidad de Chile: selfassessment and its effects on university's management. Higher Education, 75(3), 431-447. https://doi.org/10.1007/s10734-017-0148-7

Cabrera Lanzo, N. (2018). Más allá de la acreditación: gestión interna de la calidad. Una perspectiva institucional [Beyond accreditation: internal quality management. An institutional perspective]. Paper presented at the Seminario Internacional Educación Superior para el Siglo 21, Santiago, Chile.

Campo Herrera, M. S. (2018). Estudio comparativo de dos modelos de acreditación universitaria: la aplicabilidad de estándares y criterios a la Universidad Mayor de Chile (Tesis Doctoral). UNED. Universidad Nacional de Educación a Distancia (España).

Cárdenas, L., \& García, D. (2014). Gestión de procesos en educación superior: mitos, barreras y aportes [Process Management in Higher Education: Myths, barriers and contributions]. Paper presented at the Universidad Católica de Chile, X Jornadas de Gestión De Educación Superior, Santiago, Chile.

Cardoso, S. (2009). Representações estudantis da avaliação das instituições de ensino superior público [Students' social representations on the quality assessment of public higher education institutions] (Doctoral Thesis, Universidade de Aveiro, Portugal). Retrieved from https://ria.ua.pt/ bitstream/10773/3478/1/2009001207.pdf

Cardoso, S., Rosa, M. J., \& Santos, C. S. (2013). Different academics' characteristics, different perceptions on quality assessment? Quality Assurance in Education, 21(1), 96-117. https://doi. org/10.1108/09684881311293089

Cardoso, S., Rosa, M. J., \& Stensaker, B. (2015). Why is quality in higher education not achieved? The view of academics. Assessment $\mathcal{E}$ Evaluation in Higher Education, 41(6), 950-965. https://doi.org/10.10 80/02602938.2015.1052775

Cardoso, S., Rosa, M. J., \& Videira, P. (2018). Academics' participation in quality assurance: does it reflect ownership? Quality in Higher Education, 24(1), 66-81. https://doi.org/10.1080/13538322.2018.1 433113

Carpenter, S. (2018). Ten Steps in Scale Development and Reporting: A Guide for Researchers. Communication Methods and Measures, 12(1), 25-44. https://doi.org/10.1080/19312458.2017.1396583 
Carpio, B., Illesca, M., Ellis, P., Crooks, D., Droghetti, J., Tompkins, C., $\&$ Noesgaard, C. (1999). Student and faculty learning styles in a Canadian and a Chilean self-directed, problem-based nursing program. Canadian Journal of Nursing Research Archive, 31(3), 31-50. Retrieved from https://www.ncbi.nlm.nih.gov/pubmed/10696168

CIPER-CHILE. (2012). Las fallas del sistema al fiscalizar a la Universidad del Mar. CIPER-CHILE. Retrieved from http://ciperchile.cl/2012/06/07/ las-fallas-del-sistema-al-fiscalizar-a-la-universidad-del-mar/

CNA-Chile. (2019). Barómetro del aseguramiento de la calidad de la educación superior [Barometer of the quality assurance of higher education]. Retrieved from Santiago, Chile: https://investigacion.cnachile.cl/archivos/cna/ documentos/Baraometro-CNA-3.pdf

Collazo, A. A. (2005). Translation of the Marlowe-Crowne Social Desirability Scale into an Equivalent Spanish Version. Educational and Psychological Measurement, 65(5), 780-806. https://doi. org/10.1177/0013164405275660

De Vincenzi, A. (2013). Evaluación institucional y mejoramiento de la calidad educativa en tres universidades privadas argentinas [Institutional assessment and improvement of educational quality in three private Argentinian universities]. Revista Iberoamericana de Educación Superior, 4(9), 76-94. Retrieved from https://ries.universia.net/article/ viewFile/102/160

De Vincenzi, A. (2018). Percepciones de los académicos sobre la mejora de la calidad universitaria argentina. Debate Universitario, 6(12), 9-22.

Dinno, A. (2009). Exploring the Sensitivity of Horn's Parallel Analysis to the Distributional Form of Random Data. Multivariate Behavioral Research, 44(3), 362-388. https://doi.org/10.1080/00273170902938969

Dinno, A. (2012). paran: Horn's Test of Principal Components/Factors. Retrieved from http://cran.r-project.org/web/packages/paran/index. html.

Dolmans, D., Wolfhagen, H., \& Scherpbier, A. (2003). From Quality Assurance to Total Quality Management: How Can Quality Assurance Result in Continuous Improvement in Health Professions Education? Education for Health: Change in Learning \& Practice, 16(2), 210. Retrieved from http://ezpbibliotecas.udec.cl/login?url=http://search. ebscohost.com/login.aspx?direct=true $\& \mathrm{db}=$ asn $\& A N=10282219 \& 1 \mathrm{a}$ ng=es\&site=ehost-live

Dooner, C., Armanet, L., Busco, C., d'Alencon, A., \& Salomone, A. (2016). Impacto de los procesos de autoevaluación en la gestión de pregrado y postgrado en la Universidad de Chile (2011-2014). Santiago de Chile: 
354 PERCEPTIONS ABOUT ACCREDITATION AND QUALITY MANAGEMENT IN HIGHER EDUCATION. DEVELOPMENT OF A SPANISH-LANGUAGE QUESTIONNAIRE WITH A SAMPLE OF ACADEMICS FROM A PRIVATE UNIVERSITY - L. González-Bravo, D. Stanciu, N. Nistor, B. Castro, G. Puentes, M. Valdivia

Comisión Nacional de Acreditación. Serie Cuadernos de Investigación en Aseguramiento de la Calidad(2), 216.

Dzimińska, M., Fijałkowska, J., \& Sułkowski, Ł. (2018). Trust-based quality culture conceptual model for higher education institutions. Sustainability, 10(8), 2599.

Fabrigar, L. R., \& Wegener, D. T. (2012). Exploratory Factor Analysis: Understanding Statistics. New York: Oxford University Press.

Fernandez, A. R., Omar, S. Z., \& Husain, R. (2013). Development and validation of a food frequency questionnaire to estimate the intake of genistein in Malaysia. International Journal of Food Sciences and Nutrition, 64(7), 794-800. https://doi.org/10.3109/09637486.2013. 798269

Ferreyra, M. M., Avitabile, C., \& Paz, F. H. (2017). At a crossroads: Higher education in Latin America and the Caribbean: World Bank Publications.

Ganga Contreras, F. (2016). Percepción preliminar de los marcos regulatorios del sistema universitario iberoamericano: Algunos avances investigativos [Preliminary perception of regulatory frameworks of the Ibero-American university system: Some research advances]. Revista Gestão Universitária na América Latina-GUAL, 9(2), 178-191.

Glorfeld, L. W. (1995). An Improvement on Horn's Parallel Analysis Methodology for Selecting the Correct Number of Factors to Retain. Educational and Psychological Measurement, 55(3), 377-393. https://doi. org/10.1177/0013164495055003002

González-Bravo, L., Nistor, N., \& Castro Ramírez, B. (2019). Narrating in grey: An application to educational management information systems and accountability. Information Development, O(0), 0266666919894725. doi:10.1177/0266666919894725

Grandzol, J. R., \& Gershon, M. (1998). A survey instrument for standardizing TQM modeling research. International Journal of Quality Science, 3(1), 80-105. https://doi.org/10.1108/13598539810203887

Gregorutti, G., \& Bon, V. (2012). Percepciones de la efectividad de los procedimientos de evaluación y acreditación en una universidad privada [Perceptions of effectiveness of assessment and accreditation procedures in a private university]. Revista de Investigación Educativa de la Escuela de Graduados en Educación, 3(5), 2-11. Retrieved from http:// rieege.tecvirtual.mx/index.php/rieege/article/view/31/30

Grubisic, D., \& Kovacevic, V. (2010, May 26-29, 2010). Effects of quality system introduction on higher education. Paper presented at the 5tll International Conference. An Enterprise Odyssey: From Crisis to Prosperity. Challenges for Government and Business. 
Henson, R. K., \& Roberts, J. K. (2016). Use of Exploratory Factor Analysis in Published Research. Educational and Psychological Measurement, 66(3), 393-416. https://doi.org/10.1177/0013164405282485

Holgado-Tello, F. P., Chacón-Moscoso, S., Barbero-García, I., \& Vila-Abad, E. (2008). Polychoric versus Pearson correlations in exploratory and confirmatory factor analysis of ordinal variables. Quality $\&$ Quantity, 44(1), 153-166. https://doi.org/10.1007/s11135-008-9190-y

Huusko, M., \& Ursin, J. (2010). Why (not) assess? Views from the academic departments of Finnish universities. Assessment $\mathcal{E}$ Evaluation in Higher Education, 35(7), 859-869. https://doi. org/10.1080/02602930903125264

In'airat, M. H., \& Kassem, A. H. A. (2014). Total Quality Management in Higher Education: A Review. International Journal of Human Resource Studies, 4(3), 294. https://doi.org/10.5296/ijhrs.v4i3.6368

IPSOS. (2010a). Informe Ejecutivo. Estudio exploratorio sobre efectos de la Acreditación Institucional en la calidad de la educación superior en Chile [Executive Report. Exploratory study about effects of Institutional Accreditation on the quality of higher education in Chile]. Santiago, Chile Retrieved from https://www.cnachile.cl/Biblioteca\%20 Documentos\%20de\%20Interes/Estudio\%20IPSOS\%20-\%20 Informe\%20Ejecutivo.pdf

IPSOS. (2010b). Informe Final. Estudio exploratorio sobre efectos de la Acreditación Institucional en la calidad de la educación superior en Chile [Final Report. Exploratory study about effects of Institutional Accreditation on the quality of higher education in Chile]. . Santiago, Chile: IPSOS Retrieved from https://www.cnachile.cl/Biblioteca\%20Documentos\%20de\%20Interes/ Estudio\%20IPSOS\%20-\%20Informe\%20Final.pdf

Kai, J. (2009). A Critical Analysis of Accountability in Higher Education. Chinese Education \& Society, 42(2), 39-51. doi:10.2753/ced10611932420204

Kaiser, H. F. (1970). A second generation little jiffy. Psychometrika, 35(4), 401-415. https://doi.org/10.1007/BF02291817

Kaiser, H. F. (1974). An index of factorial simplicity. Psychometrika, 39(1), 31-36. https://doi.org/10.1007/BF02291575

Kauko, J. (2014). Complexity in higher education politics: bifurcations, choices and irreversibility. Studies in Higher Education, 39(9), 16831699. https://doi.org/10.1080/03075079.2013.801435

Kleijnen, J. (2012). Internal quality management and organisational values in higher education: conceptions and perceptions of teaching staff (Doctoral 
356 PERCEPTIONS ABOUT ACCREDITATION AND QUALITY MANAGEMENT IN HIGHER EDUCATION. DEVELOPMENT OF A SPANISH-LANGUAGE QUESTIONNAIRE WITH A SAMPLE OF ACADEMICS FROM A PRIVATE UNIVERSITY - L. González-Bravo, D. Stanciu, N. Nistor, B. Castro, G. Puentes, M. Valdivia

dissertation, Maastricht University, Netherlands). Retrieved from https:// cris.maastrichtuniversity.nl/ws/files/1402717/guid-ba5f87d8-96774068-afd0-b5f613914178-ASSET1.0

Kleijnen, J., Dolmans, D., Willems, J., \& van Hout, H. (2011). Does internal quality management contribute to more control or to improvement of higher education? Quality Assurance in Education, 19(2), 141-155. doi:10.1108/09684881111125041

Knekta, E., Runyon, C., \& Eddy, S. (2019). One Size Doesn't Fit All: Using Factor Analysis to Gather Validity Evidence When Using Surveys in Your Research. CBE life sciences education, 18(1), rml-rml. https://doi. org/10.1187/cbe.18-04-0064

Kruempel, B. (1990). Attitudes of academic and student affairs administrators toward student affairs preparation programs and their accreditation (Doctoral dissertation, Iowa State University, Ames, Iowa). Retrieved from http://lib.dr.iastate.edu/cgi/viewcontent. cgi?article $=10449 \&$ context $=$ rtd

Lafont, P. (2014). Knowledge Producing of the Doctoral Thesis: Between Scientific Utility and Social Usage. Procedia - Social and Behavioral Sciences, 116, 570-577. https://doi.org/10.1016/j.sbspro.2014.01.259

Larrauri, J. O., Espinosa, E. M., Rosario Muñoz, V. M., \& Lechosa, D. P. (2012). Los académicos frente a la gestión de la calidad en las instituciones de educación superior. Percepción y valoración [The academics face the management of quality in higher education institutions. Perception and valuation]. Avaliação: Revista da Avaliação da Educação Superior (Campinas), 17(3), 689-712. https://doi. org/10.1590/s1414-40772012000300007

Laughton, D. (2003). Why was the QAA approach to teaching quality assessment rejected by academics in UK HE? Assessment $\mathcal{E}$ Evaluation in Higher Education, 28(3), 309-321. https://doi. org/10.1080/0260293032000059658

Lemaitre, M. J. (2019). Diversidad, autonomía, calidad. Desafíos para una educación superior para el siglo XXI. Santiago, Chile: CINDA.

Lemaitre, M. J., \& Anderson, M. (2010). Quality assurance in Latin America. Paper presented at the Annual Conference of Council for Higher Education Accreditation. https://www.chea.org/userfiles/ Conference\%20Presentations/2010_IS_Quality_Assurance_in_Latin_ America_AndersonLemaitre.pdf

Lemaitre, M. J., Maturana, M., Zenteno, E., \& Alvarado, A. (2012). Cambios en la gestión institucional en universidades, a partir de la implementación del sistema nacional de aseguramiento de la calidad: la experiencia 
chilena [Changes in institutional management in universities, from the implementation of the national system of quality assurance: the Chilean experience]. Calidad en la Educación(36), 21-52.

Lemaitre, M. J., Maturana, M., Zenteno, M. E., \& Alvarado, A. (2011). Cambios en la gestión institucional del aseguramiento de la calidad en las universidades, a partir de la implementación del Sistema nacional de aseguramiento de la calidad: la experiencia chilena [Changes in institutional management of quality assurance at universities, from the implementation of the national system of quality assurance: the Chilean experience]. Retrieved from https://www.cned.cl/file/1923/download?token=XtbvkRtB

Lewis, S. (2016). Perceptions of university faculty regarding accreditation in a college of education (Doctoral dissertation, University of South Florida, Florida). Retrieved from https://scholarcommons.usf.edu/cgi/ viewcontent.cgi?referer=https://www.google.com/\&httpsredir=1\&ar ticle $=7496 \&$ context $=$ etd

Li, C.-H. (2016). Confirmatory factor analysis with ordinal data: Comparing robust maximum likelihood and diagonally weighted least squares. Behavior research methods, 48(3), 936-949. https://doi.org/10.3758/ s13428-015-0619-7

Loukkola, T., \& Zhang, T. (2010). Examining quality culture: Part 1-Quality assurance processes in higher education institutions. Retrieved from https://eua.eu/resources/publications/406:examining-quality-culturepart-i-quality-assurance-processes-in-higher-education-institutions. html

Manatos, M. J., Sarrico, C. S., \& Rosa, M. J. (2017). The integration of quality management in higher education institutions: a systematic literature review. Total Quality Management \& Business Excellence, 28(1-2), 159175.

Martínez Iñiguez, J. E., Tobón Tobón, S., \& Romero Sandoval, A. (2017). Problemáticas relacionadas con la acreditación de la calidad de la educación superior en América Latina. Innovación educativa (México, DF), 17, 79-96. Retrieved from http://www.scielo.org.mx/scielo. php?script=sci_arttext\&pid=S1665-26732017000100079\&nrm=iso

Milne, T., Creedy, D. K., \& West, R. (2016). Development of the Awareness of Cultural Safety Scale: A pilot study with midwifery and nursing academics. Nurse Education Today, 44, 20-25. https://doi.org/10.1016/j. nedt.2016.05.012

Mizikaci, F. (2006). A systems approach to program evaluation model for quality in higher education. Quality Assurance in Education, 14(1), 3753. https://doi.org/10.1108/09684880610643601 
358 PERCEPTIONS ABOUT ACCREDITATION AND QUALITY MANAGEMENT IN HIGHER EDUCATION. DEVELOPMENT OF A SPANISH-LANGUAGE QUESTIONNAIRE WITH A SAMPLE OF ACADEMICS FROM A PRIVATE UNIVERSITY - L. González-Bravo, D. Stanciu, N. Nistor, B. Castro, G. Puentes, M. Valdivia

Muñoz, D. A. (2016). Assessing the research efficiency of higher education institutions in Chile: A data envelopment analysis approach. International Journal of Educational Management, 30(6), 809-809-825. https://doi.org/10.1108/IJEM-03-2015-0022

NEASC. (2006). The impact of accreditation on the quality of education: results of the regional accreditation \& quality of education survey, NEASC 2005. Retrieved from Bedford, USA:

Newton, J. (2002). Views from below: academics coping with quality. Quality in Higher Education, 8(1), 39-61. Retrieved from http://citeseerx.ist.psu. $\mathrm{edu} /$ viewdoc/download?doi=10.1.1.195.5243\&rep=repl\&type=pdf

Ngwenya, T. (2003). Quality assurance in south african higher education and its implementation at the University of Durban-Westville (Master's Thesis, University of South Africa, Pretoria). Retrieved from http://uir.unisa. ac.za/handle/10500/1615

Patil, V., Surendra, N. S., Sanjay, M., \& Donavan, T. (2007). Parallel analysis engine to aid determining number of factors to retain. Retrieved from https://analytics.gonzaga.edu/parallelengine/

Pedraja-Rejas, L., \& Rodríguez-Ponce, E. (2015). The quality assurance: A strategic imperative in higher education. Ingeniare. Revista chilena de ingeniería, 23(1), 4-5. https://doi.org/10.4067/s071833052015000100001

Pratasavitskaya, H., \& Stensaker, B. r. (2010). Quality management in higher education: Towards a better understanding of an emerging field. Quality in Higher Education, 16(1), 37-50.

Proyecto Alpha. (2011). Proyecto ALFA III: "Aseguramiento de la calidad: políticas públicas y gestión universitaria”. Primeros resultados de la evaluación de impacto [ALFA III project "Quality assurance: public policy and university management." Impact assessment first results]. Paper presented at the Red Iberoamericana para la Acreditación de la Educación Superior, RIACES, VI Seminario internacional acreditación de la calidad de la educación superior, San José, Costa Rica.

Pulido-Roccatagliata, S., \& Espinoza-Díaz, O. (2018). Aseguramiento de la calidad en la educación superior de Chile: Alcance, implicaciones y aspectos críticos. Revista Venezolana de Gerencia, 23(1), 238-255.

Putnam, T. E. M. (2000). Tribal college and university accreditation: a comparative study (Doctoral dissertation). University of Texas at Austin, Available from ERIC (ED458866)

R Core Team. (2017). R: a language and environment for statistical computing. Viena, Austria: R Foundation for Statistical Computing. Retrieved from https://www.R-project.org 
Revelle, W. (2018). psych: procedures for psychological, psychometric, and personality research: Northwestern University. Retrieved from https:// CRAN.R-project.org/package=psych

Rojas Ríos, M. J., \& López Stefoni, D. A. (2016). La acreditación de la gestión institucional en universidades chilenas. Revista Electrónica de Investigación Educativa, 18(2), 180-190. Retrieved from https://redie. uabc.mx/redie/article/view/856

Ruiz, V. M., Berrocal, C., López, A. E., \& Rivas, T. (2002). Factor Analysis of the Spanish Version of the Weight Efficacy Life-Style Questionnaire. Educational and Psychological Measurement, 62(3), 539-555. https:// dx.doi.org/10.1177/00164402062003010

Salas Durazo, I. A. (2013). La acreditación de la calidad educativa y la percepción de su impacto en la gestión académica: el caso de una institución del sector no universitario en México [The accreditation of educational quality and the perception of its impact on academic management: the case of an institution of the non-university sector in Mexico]. Calidad en la Educación(38), 305-333. https://dx.doi. org/10.4067/s0718-45652013000100009

Salazar, J. (2008). Diagnóstico preliminar sobre evaluación de la docencia universitaria. Una aproximación a la realidad en las universidades públicas y/o estatales de Chile [Preliminary diagnosis on evaluation of university teaching. An approach to reality in public/state universities in Chile]. Revista Iberoamericana de Evaluación Educativa, 1(3), 67-84.

Scharager, J. (2017). Nuevos actores en un viejo escenario: la profesionalización de la gestión de la calidad académica en Chile, 1990-2015 [New actors in an old scenario: the professionalization of academic quality management in Chile, 1990-2015]. (Doctor). University of Leiden, Nederland.

Scharager, J., \& Rodríguez Anaiz, P. (2019). Identidad Profesional de los administradores de la calidad en universidades chilenas: entre la invisibilización y la burocratización. Calidad en la Educación(50), 30. https://doi.org/10.31619/caledu.n50.538

Schroeder, K. E. (2008). A study of the differences between managers and non-managers in their perceptions of quality management achievement (Unpublished doctoral dissertation). Lawrence Technological University, Michigan.

Stensaker, B., Langfeldt, L., Harvey, L., Huisman, J., \& Westerheijden, D. (2011). An in-depth study on the impact of external quality assurance. Assessment \& Evaluation in Higher Education, 36(4), 465-478. https:// doi.org/10.1080/02602930903432074 
360 PERCEPTIONS ABOUT ACCREDITATION AND QUALITY MANAGEMENT IN HIGHER EDUCATION. DEVELOPMENT OF A SPANISH-LANGUAGE QUESTIONNAIRE WITH A SAMPLE OF ACADEMICS FROM A PRIVATE UNIVERSITY - L. González-Bravo, D. Stanciu, N. Nistor, B. Castro, G. Puentes, M. Valdivia

Taskov, N., \& Mitreva, E. (2015). The motivation and the efficient communication both are the essential pillar within the building of the TQM (Total Quality Management) system within the Macedonian higher education institutions. Procedia - Social and Behavioral Sciences, 180, 227-234. https://doi.org/10.1016/j.sbspro.2015.02.109

Toro, J. (2012). Gestión interna de la calidad en las instituciones de educación superior [Internal quality management in higher education institutions]. Santiago, Chile: CINDA/ RIL Editores.

Trakman, L. (2008). Modelling university governance. Higher Education Quarterly, 62(1-2), 63-83. https://doi.org/10.1111/j.14682273.2008.00384.x

Trullen, J., \& Rodríguez, S. (2013). Faculty perceptions of instrumental and improvement reasons behind quality assessments in higher education: the roles of participation and identification. Studies in Higher Education, 38(5), 678-692. https://doi.org/10.1080/03075079.2011.590587

Vásquez, A. (2015). Políticas y procesos de aseguramiento de la calidad de la educación universitaria en chile: experiencia y percepciones de sus principales actores [Policies and processes for quality assurance of higher education in Chile: Experience and perceptions of the main actors] (Doctoral dissertation, Universidad de Sevilla, España). Spain. Retrieved from https://idus.us.es/xmlui/handle/11441/36946

Venables, J. P., \& Van Gastel, J. (2014). Radiografía de los modelos de acreditación: organización, procesos y prácticas. El caso de las universidades Austral de Chile, De la Frontera y De los Lagos [Radiography of accreditation models: organization, processes and practices. The case of Universities Austral de Chile, De la Frontera y De los Lagos]. Calidad en la Educación(41), 51-81.

Vera-Millalén, F. (2018). Percepción de estudiantes respecto de la calidad educativa y organizacional de la carrera de enfermería de una universidad privada chilena. Revista Electrónica Educare, 22, 1-25. Retrieved from http://www.scielo.sa.cr/scielo.php?script=sci_ arttext\&pid=S1409-42582018000300001\&nrm=iso

Vieira, F. (2002). Pedagogic quality at university: what teachers and students think. Quality in Higher Education, 8(3), 255-272. https:// doi.org/10.1080/1353832022000031647

Viloria-Escobar, J., Bertel-Narváez, M., \& Daza-Corredor, A. (2015). Percepciones estudiantiles sobre el proceso de acreditación por alta calidad del Programa de Administración de Empresas de la Universidad del Magdalena. Praxis, 11(1), 89-102. 
Volkwein, J. F., Lattuca, L. R., Harper, B. J., \& Domingo, R. J. (2007). Measuring the impact of professional accreditation on student experiences and learning outcomes. Research in Higher Education, 48(2), 251-282. https://doi.org/10.1007/s11162-006-9039-y

Watty, K. (2006). Want to know about quality in higher education? ask an academic. Quality in Higher Education, 12(3), 291-301. https://doi. org/10.1080/13538320601051101

Westerheijden, D. F., Stensaker, B., Rosa, M. J., \& Corbett, A. (2014). Next Generations, catwalks, random walks and arms races: conceptualising the development of quality assurance schemes. European Journal of Education, 49(3), 421-434. https://doi.org/10.1111/ejed.12071

Zapata, G., \& Torre, D. (2012). Impacto de procesos de aseguramiento de la calidad sobre las instituciones de educación superior: un estudio en siete países. In M. Lemaitre (Ed.), Aseguramiento de la calidad en Iberoamérica: educación superior informe 2012 [Quality assurance in Latin America: higher education 2012 report] (pp. 117-153). Santiago, Chile: Centro Interuniversitario de Desarrollo, CINDA. 

OF ACADEMICS FROM A PRIVATE UNIVERSITY - L. González-Bravo, D. Stanciu, N. Nistor, B. Castro, G. Puentes, M. Valdivia

\section{Appendix 1: Table 5. Questionnaire items (in English and Spanish)}

1. The accreditation process fulfilled the function of publicly ensuring the quality of my institution / El proceso de acreditación cumplió con la función de asegurar públicamente la calidad de mi institución.

2. The accreditation process fulfilled the function of promoting quality in my institution / El proceso de acreditación cumplió la función de promover la calidad en mi institución.

3. in the accreditation process was useful for the faculty and staff of my institution / La participación en el proceso de acreditación fue útil para el profesorado y el personal de mi institución.

4. The accreditation process helped clarify important strengths and concerns of the institution / El proceso de acreditación ayudó a aclarar fortalezas y preocupaciones importantes de la institución.

5. The accreditation process helped my institution gain momentum by addressing significant issues related to accreditation standards / El proceso de acreditación ayudó a mi institución a ganar impulso al abordar temas significativos relacionados con los estándares de acreditación.

6. The accreditation process motivates my institution to focus more on assessing student learning / El proceso de acreditación motiva a mi institución a centrarse más en la evaluación del aprendizaje de los estudiantes.*

7. The standards set by the CNA are realistic / Los estándares establecidos por la CNA son realistas.

8. The evaluators' recommendations were valid and exhaustive / Las recomendaciones de los evaluadores fueron válidas y exhaustivas.

9. My institution received adequate training on how to prepare for an accreditation visit / Mi institución recibió capacitación adecuada sobre cómo prepararse para una visita de acreditación.

10. The accreditation process is one of the most important factors in ensuring educational improvement in Chile / El proceso de acreditación es uno de los factores más importantes para asegurar el mejoramiento educativo en Chile.

11. I would worry that the educational quality of higher education institutions could deteriorate if the accreditation process were to end in Chile / Me preocuparía que la calidad educativa de las instituciones de educación superior pudiera deteriorarse si el proceso de acreditación terminara en Chile.

12. One of the central functions of the (Quality Unit) at (mention the institution) should be staff development to improve the quality of teaching and learning / Una de las funciones centrales de la (Unidad de Calidad) de (mencionar la institución) debe ser la capacitación en temas académicos para el personal, para mejorar la calidad de la enseñanza y el aprendizaje.

13. The (Quality Unit) at (mention the institution) should design programmes for university-wide curriculum development / La (Unidad de Calidad) de (mencionar la institución) debe participar del diseño de los programas para el desarrollo curricular de toda la universidad.

14. The (Quality Unit) in (mention the institution) must participate in the design of the trainings for the academics to improve the quality of teaching and learning / La (Unidad de Calidad) en la (mencionar la institución) debe participar en el diseño de las capacitaciones a los académicos para mejorar la calidad de la enseñanza y el aprendizaje. 
15. Students should evaluate the content of all modules for which they are registered / Los estudiantes deben evaluar el contenido de todas las asignaturas inscritas.*

16. Students should evaluate the presentation of all modules for which they are registered / Los estudiantes deben evaluar la presentación y forma de todas las asignaturas inscritas. *

17. The organization and management model of the (mention the institution) encourages the evaluation and continuous improvement of all its services and processes / La organización y el modelo de gestión de la (mencionar la institución) fomenta la evaluación y mejora continua de todos sus servicios y procesos.*

18. Quality management is part of the normal working practices of all staff members in my academic unit / La gestión de la calidad es parte de las prácticas normales de trabajo de todos los miembros del personal de mi unidad académica.*

Note for the table: * Designates items kept only in model 2 (6F). 